\title{
Does Oil Price Volatility Drive Household Consumption Expenditures in Nigeria?
}

\author{
Jimoh Sina Ogede
}

\begin{abstract}
This paper investigates whether volatilities in oil prices influence consumer household consumption expenditure from 1995 to 2019, a period described in the literature by the weakening effect of oil price volatility on macroeconomic factors. The Vector autoregressive model's findings suggest that the unexpected changes in oil prices significantly influence household consumption expenditure in Nigeria. A one standard deviation unexpected for a change in oil prices corresponds to a 28.31 percent increase in Nigeria's consumption expenditure. Moreover, the decomposition of the variance did not affect the sign and significance of the household relationship between oil price volatility and consumption expenditure. The paper offers that the extent to which dependence on oil continues depends on the magnitude to which Nigeria's economies can continue developing alternative energy sources and improving energy conservation.
\end{abstract}

Keywords: oil price, realized volatility, consumption expenditure

\begin{abstract}
Abstrak
Penelitian ini menyelidiki apakah volatilitas harga minyak mempengarubi pengeluaran konsumsi rumah tangga konsumen dari tahun 1995 hingga 2019, suatu periode yang dijelaskan dalam literatur oleh pengaruh pelemahan volatilitas harga minyak pada faktor makroekonomi. Temuan Vector Autoregressive model menunjukkan bahwa perubahan tak terduga dalam harga minyak cenderung mempengaruhi perubahan pengeluaran konsumsi rumah tangga di Nigeria secara signifikan. Sebuah deviasi standar yang tidak terduga untuk perubahan harga minyak sama dengan peningkatan 28,31 persen dalam pengeluaran konsumsi Nigeria. Selain itu, penguraian varians tidak mempengarubi tanda dan signifkansi hubungan rumah tangga antara volatilitas harga minyak dan pengeluaran konsumsi. Penelitian ini menawarkan sejauh mana ketergantungan pada minyak terus bergantung pada seberapa besar ekonomi Nigeria dapat terus mengembangkan sumber energi alternatif dan meningkatkan konservasi energi.
\end{abstract}

Kata Kunci: harga minyak, volatilitas terwujud, pengeluaran konsumsi

JEL classification: D15, Q43

\section{How to Cite:}

Ogede, J. S. (2020). Does Oil Price Volatility Drive Household Consumption Expenditures in Nigeria? Signifikan: Jurnal Ilmu Ekonomi, 9(2), 257-268. doi: http://doi.org/10.15408/sjie.v9i2.15498. 


\section{Introduction}

Ever since Hamilton's research (1983), the empirical literature on the link between oil prices and economic output has rigorously question, yielding several empirical predictabilities for diverse nations. The first standpoint argued that oil prices had a significant impact on economic performance (see Hamilton, 2005; Lescaroux \& Mignon, 2008; Kilian, 2010; Baumeister \& Kilian; 2017; Ogede et al., 2020). Another viewpoint focused on whether oil price shocks have a symmetric or asymmetric effect on the economy (see Ferderer, 1996; Cologni \& Manera, 2009; Edelstein \& Kilian, 2009; Hamilton, 2011; Kilian \& Vigfussion, 2014; Baumeister \& Kilian, 2017). Another standpoint focused on the relation between the changes in oil prices and household's purchasing power or consumer spending (see Mehra \& Peterson, 2005; Edelstein \& Kilian, 2009; Odusami, 2010; Zhang \& Broadstock, 2014; Zaman, 2015; Baumeister et al., 2017; Baumeister \& Kilian, 2017; Alsalman \& Karaki, 2019). From these studies, the uncertainties induced by oil price fluctuations are decreasing consumer confidence and stimulating consumers to take precautionary savings actions at present consumption's opportunity cost. In contrast, other studies argued that the economic impact of oil price volatility had decreased significantly (Edelstein \& Kilian, 2007; Blanchard \& Gali, 2007; Iwayemi \& Fowowe, 2011; Blanchard \& Riggi, 2013; Ramey, 2016). This condition resulted from advances in alternative energy sources, changes in the firm production model to relatively small energy-demanding enterprises and enhanced monetary policy efficiency to sustain prices (Blanchard \& Gali, 2007; Iwayemi \& Fowowe, 2011; Blanchard \& Riggi, 2013).

However, the recent unprecedented decline in crude oil prices and its antecedents have attracted the attention of various stakeholders to the nexus between the crucial factor input prices and the economic output. An immediate consequence of the volatility of oil prices in a country that is highly dependent on imported goods and the importation of factor inputs from developed countries is that any change in oil prices would cause imports to be costly and thus raise energy-intensive commodity production costs and further boost consumer prices (Blanchard \& Gali, 2008). Unequivocally, the effect of sudden changes in oil prices on oil-exporting countries like Nigeria cannot exaggerate. As oil prices dipped further and continue to resolve around $\$ 10$ to $\$ 20$ per barrel in the first month of the 2 nd quarter of 2020, surpassing the benchmark anticipated by the Nigerian government. The dwindling in oil prices have forced the Nigerian government battling to respond to one of the severe and time-bound oil price decreases. The current oil price shock suggests that the $\$ 57$ benchmark may not be realistic, and the government's need to review her budget becomes sacrosanct. As changes in the crude oil price deepen, the economy began to experience changes in consumption budget and businesses due to fluctuations in discretionary income (Baumeister et al., 2017).

Besides, it seems plausible to a large extent that empirical literature has thrived on the empirical relationship between changes in oil prices and economic forces; the empirical assessment focuses on the implications of the volatilities of oil prices on aggregate consumption has been relatively scarce. This paper extends the literature on the impact of oil price volatility on the economic output by converging on household spending consumption that perhaps is 
the principal constituent of gross domestic product. This paper investigates the impact of oil price volatility on household consumption spending in Nigeria, noting the general slowdown in household consumption spending compelled by the global financial crisis in 2008 and due to Nigeria's excessive records of remarkable income disparity and poverty index classification. The current status of the country shows that there are inequalities in income. This paper is the first to investigate the oil price volatility and household consumption expenditure nexus in Nigeria. Explicitly, the paper investigates the impacts of oil price volatility on household consumption expenditure by drawing upon the consumption theory; and integrates income and wealth as well as realized volatility as proxies.

Unlike, the previous studies (see Narayan \& Narayan, 2007; Wang and Wu, 2012; Salisu \& Fasanya, 2013; Narayan \& Gupta, 2015) that modeled oil price volatility around the GARCH-family models, this paper explored realized volatility (RV) model to measure oil price volatility. The RV is estimated as the sum of squared intra-day returns (Andersen $\&$ Bollerslev, 1998), and provides an unbiased and highly efficient estimator of the volatility of returns (Chen \& Hsu, 2012). The paper also examines the possible effect of oil price volatility on Nigeria's household consumption expenditure using time series data from 2000 to 2019. The period before the 1990s excludes estimating the most recent fluctuations in the price of crude oil. However, this study's ingenuity will help policymakers with the crucial tools for developing policy responses that mitigate the hostile effects of oil price volatility on consumption expenditure in Nigeria. The rest of the study is structured as follows. Section two discusses relevant empirical literature, while section three offers methodology. Section four presents the discussion of results and findings. Section five concludes the study.

\section{Methods}

A fundamental assumption in the literature is that consumption depends entirely on disposable income, such that when average disposable income increases, the consumption expenditure increases in an economy, and vice versa. Given the focus of the study is on clarifying the diverse reaction of the household consumption to oil price volatility in the period of review, noting the general conduct of how oil prices influence the economy, and allowing effects on consumption expenditure.

This paper is a prototype of Mehra and Peterson (2005), who specify based on theories of the permanent income of Friedman (1957) and the life-cycle hypotheses of Ando \& Modigliani (1963). The consumption expenditure model specifies:

$\Delta C E_{t}=\beta_{0}+\beta_{1}\left(C E_{t-1}^{p}-C E_{t-1}\right)+\beta_{2} \Delta Y_{t-1}+\beta_{3} \Delta W_{t-1}+\sum_{s=1}^{k} \beta_{4 s} \Delta C E_{t-s}+\mu_{t}$

where,

$C E_{t}^{p}=w_{0}+w_{1} Y_{t}+w_{2} W_{t}$

Equation (1) captures the influence of consumption fluctuations in the long and short run. Here the error correction term determines the long-run relationship. The study modified the equation by including oil price volatility measure and the interest rate as exogenous variables in equation (1) to become: 
$\Delta C E_{t}=\beta_{0}+\beta_{1}\left(C E_{t-1}^{p}-C E_{t-1}\right)+\beta_{2} \Delta Y_{t-1}+\beta_{3} \Delta W_{t-1}+\sum_{s=1}^{k} \beta_{4 s} \Delta C E_{t-s}+$

$\sum_{s=1}^{k} \beta_{5 s} \Delta R V_{t-s}+\sum_{s=1}^{k} \beta_{6 s} \Delta I R_{t-s}+\mu_{t}$

While equation (2) becomes:

$C E_{t}^{p}=w_{0}+w_{1} Y_{t}+w_{2} W_{t}+w_{3} R V_{t-1}+w_{4} I R_{t-1}$

Thus, the paper assumes that the current consumption expenditure hinges on the lagged values of net wealth, income, oil prices, and interest rate. Then, the model equation (3) is modified to become:

$\Delta C E_{t}=\beta_{0}+\beta_{1} \Delta Y_{t-1}+\beta_{2} \Delta W_{t-1}+\sum_{s=1}^{k} \beta_{3} \Delta C E_{t-1}+\sum_{s=1}^{k} \beta_{4} \Delta R V_{t-1}+$

$\sum_{s=1}^{k} \beta_{5} \Delta I R_{t-1}+\mu_{t}$

This paper explored the time series data consumption expenditure measured with Households and NPISHs Final consumption expenditure and other variables such as interest rates and measures of oil price volatility. The interest rate was introduced to gauge the monetary policy link due to oil price changes. The OPEC annual crude oil prices were considered and transformed in calculating the annual oil price volatility as specified in equation (6) in divergence to studies such as Mehra \& Peterson (2005), Odusami (2010), Zhang \& Broadstock (2014), Zaman (2015), Baumeister et al. (2017) and Alsalman \& Karaki (2019) that examine the impact of oil price shocks on consumption expenditure. This paper explored the realized volatility (RV) model to measure oil price volatility. The RV model uses the sum of squared intraday returns and can generate more true volatility measures. In this paper, the $\mathrm{RV}$ model is estimated as the sum of squared intra-year returns and is structured as thus:

$O P V_{t}=R V_{t}=\sum_{t=1}^{D} r_{t}^{2}$

Where $O P V_{t}$ represents the oil prices at time $t, R V_{t}$ stands for the realized volatility while the $r_{t}^{2}$ represents that intra-year return at time $t$. All the data were retrieved from World Development Indicator (WDI) except oil price. Households and NPISHs Final consumption expenditure, net national income per capita, and interest rate were transformed into its natural logarithm to account for relative variations in the model.

Due to the cutting-edge advantages, the Vector Autoregressive (VAR) model has proven to be crucial and reliable for forecasting and for explaining the dynamic behaviour of economic time series. Forecasts from VAR models are relatively flexible because they can be made conditional on the potential future paths of identified variables in the model. Besides, the VAR model is also explored in this paper to gauge structural inference and policy analysis. Given the structural implication, certain rules about the causal structure of the data under investigation were imposed, and the resulting causal effects of unexpected shocks to specified variables on the variables in the VAR model. The VAR model is due to the presence of the lagged value of the consumption expenditure while vector is ultimate because we are dealing with a vector of two or more variables.

The paper assumed that each equation contains $k$ lag values of each explanatory variable. Hereafter, equation 5, and (6) become model equation (7) explored in the paper as follows:

$\Delta C E_{t}=\beta_{0}+\sum_{j=1}^{k} \beta_{1} \Delta C E_{t-1}+\sum_{j=1}^{k} \beta_{2} \Delta Y_{t-1}+\sum_{j=1}^{k} \beta_{3} \Delta W_{t-1}+\sum_{j=1}^{k} \beta_{4} \Delta R V_{t-1}+$ $\sum_{j=1}^{k} \beta_{5} \Delta I R_{t-1}+\mu_{t}$ 
Where the error term is depicted by $\mu$ that denotes all variations in consumption expenditure that cannot be described by the incorporated explanatory variables. However, the paper adopted three level's procedural steps to estimate the VAR model. These include the pre-estimation phase focuses on a preliminary assessment of the data using the descriptive statistics; determination of the stability of the variables. These were carried out through the Augmented Dickey-fuller (ADF), Phillips-Perron unit root tests, and the Johansen cointegration test as well as the selection of optimal lag length. The Johansen co-integration test was explored to ascertain the long-run relationship between the variables. The third phase deals with estimation and post- estimation. The estimation focuses only on the estimation of vector autoregressive (VAR) to establish whether oil price volatility increases or decreases consumer spending in Nigeria. This phase also considers post estimation tests to validate the VAR regression model.

\section{Result and Discussions}

Table 1 presents the median and means of all the observations in the data set lie within the maximum and minimum values demonstrating the high tendency of the normal distribution. All data sets are positively skewed. The kurtosis statistics showed that consumption expenditure, oil price volatility, national per capita, and interest rate were platykurtic, signifying that data set distributions were flat compared with a normal distribution. The Jarque-Bera statistics reveal that the series normally distributed given the p-values of consumption expenditure, national per capita, and interest rate are not statistically significant at a 5\% level. Besides, the reverse is the case because of the oil price volatility.

Table 1. Descriptive Statistics of the Variables

\begin{tabular}{lcccc}
\hline \multicolumn{1}{c}{ Description } & LnCE & RV & LnYC & LnIR \\
\hline Mean & 24.81400 & 1.220419 & 6.672600 & 2.855463 \\
Median & 24.25812 & 1.003518 & 6.579288 & 2.872982 \\
Maximum & 26.75102 & 3.988784 & 7.877645 & 3.454738 \\
Minimum & 23.29048 & 0.023566 & 5.238802 & 2.244250 \\
Std. Dev. & 1.164011 & 1.019060 & 0.747669 & 0.282200 \\
Skewness & 0.423550 & 1.255945 & 0.059734 & -0.684264 \\
Kurtosis & 1.610381 & 4.051635 & 1.696161 & 3.409904 \\
Jarque-Bera & 3.972931 & 11.12330 & 2.571405 & 3.061334 \\
& $(0.137179)$ & $(0.003842)$ & $(0.276456)$ & $(0.216391)$ \\
\hline
\end{tabular}

Source: Eview computation (2020)

Table 2 presents the correlation matrix of the data set. The results show that the variables' coefficients are less than 0.95 , suggesting that there is no inclination for multicollinearity to ensue amongst the explanatory variables. 
Table 2. Correlation matrix

\begin{tabular}{ccccc}
\hline & LNCE & RV & LNYC & LNIR \\
\hline LNCE & 1 & & & \\
RV & 0.13290 & 1 & & \\
LNYC & 0.86171 & 0.09067 & 1 & \\
LNIR & -0.04518 & -0.09936 & -0.42947 & 1 \\
\hline
\end{tabular}

Source: Eview computation (2020)

Table 3 presents the results of the calculated ADF and PP unit roots at the level and difference established to be significant at $1 \%$ or $5 \%$ levels. This result confirms that the variables are indeed stationary. Besides, some variables were found stationary only with intercept. Perhaps, the literature suggests that challenges attributed to Augmented Dickeyfuller use linked to the inability of the test to correctly estimate both slope of the trend intercept in the presence of a unit root. Hence, the paper further explored the Phillips-Perron (PP) Unit Root test to verify the status of the concerned variables and the results. For all series, the test results are significant with PP at 5\%, which confirms the ADF results again. In the meantime, unit root testing results assume that all variables are in order one integrated.

Table 3. Augmented Dickey-fuller (ADF) and Phillips-Perron (PP) Unit Root Tests

\begin{tabular}{ccccc}
\hline & \multicolumn{2}{c}{ Augmented Dickey-fuller (ADF) } & \multicolumn{2}{c}{ Phillips-Perron (PP) } \\
\hline Variable & T-statistics & P-value & T-statistics & P-value \\
\hline LnCE & $-6.281250^{*}$ & 0.0000 & $-6.281585^{*}$ & 0.0000 \\
LnYC & $-4.403453^{*}$ & 0.0013 & $-4.385496^{*}$ & 0.0014 \\
LnIR & $-5.955744^{*}$ & 0.0000 & $-5.961143^{*}$ & 0.0000 \\
RV & $-5.852707^{*}$ & 0.0000 & $-6.340694^{*}$ & 0.0000 \\
\hline
\end{tabular}

Note: ${ }^{* *} 5 \%, * 1 \%$

Source: Eview computation (2020)

The papers selected the optimal lag length, which residuals are serial uncorrelated and focus on the Akaike Information Criterion (AIC) to indicate optimal lag length. The result in Table 4 exhibits several optimal lag order selection criteria. The Schwarz information criteria (SIC) depicting lag order length of (1) were selected.

Table 4. Optimal Lag Order Selection Criteria

\begin{tabular}{ccccccc}
\hline Lag Length & LogL & LR & FPE & AIC & SC & HQ \\
\hline 0 & -69.32018 & NA & 0.001149 & 4.582511 & 4.765728 & 4.643243 \\
1 & 14.80601 & $141.9630^{*}$ & $1.64 \mathrm{e}^{-05^{*}}$ & 0.324624 & $1.240709^{*}$ & $0.628280^{*}$ \\
\hline
\end{tabular}

Notes: ${ }^{*}$ indicates lag order selected by the criterion

Where LR: sequentially modified LR test statistic (each test at 5\% level); FPE: Final prediction error; AIC: Akaike information criterion; SC: Schwarz information criterion; HQ: Hannan-Quinn information criterion

Source: Eview computation (2020) 
The result of the Johansen Co-integration test shows in Table 5. The results exhibit both the Trace Statistic and Maximum Eigen Value. The result suggests a long-run nexus between real consumption expenditure, oil price volatility, national per capita, and interest rate due to rejection of the null hypothesis at $5 \%$ level of significance.

Table 5. The Result of Johansen Co-integration test

\begin{tabular}{lccccccc}
\hline $\begin{array}{c}\text { Assumed No. } \\
\text { of CE(s) }\end{array}$ & $\begin{array}{c}\text { Eigen } \\
\text { value }\end{array}$ & $\begin{array}{c}\text { Trace } \\
\text { Statistic }\end{array}$ & $\begin{array}{c}\text { Critical } \\
\text { Value }\end{array}$ & Prob. $^{* *}$ & $\begin{array}{c}\text { Max- } \\
\text { Eigenvalue }\end{array}$ & $\begin{array}{c}\text { Critical } \\
\text { Value }\end{array}$ & Prob. $^{* *}$ \\
\hline None ${ }^{*}$ & 0.57 & 64.35 & 47.86 & 0.00 & 0.575962 & 27.58434 & 0.0311 \\
At most 1 & 0.46 & 35.17 & 29.79 & 0.01 & 0.460689 & 21.13162 & 0.0523 \\
At most 2 & 0.33 & 14.18 & 15.49 & 0.07 & 0.332196 & 14.26460 & 0.0606 \\
At most 3 & 0.01 & 0.46 & 3.84 & 0.49 & 0.013319 & 3.841466 & 0.4996 \\
\hline
\end{tabular}

Notes: Trace test indicates 2 cointegrating equationOn(s) at the 0.05 level; ${ }^{*}$ denotes rejection of the hypothesis at the 0.05 level; ** MacKinnon-Haug-Michelis (1999) p-values

Source: Eview computation (2020)

The contemporaneous response of consumption expenditure to Cholesky one-squared variances of oil price shocks (RV) presents in Table 5. Each graph, as shown in plots in Figure 1 , includes a point estimation of impulse response functions as well as lower and upper bounds for a $95 \%$ confidence interval.

Figure 1. Impulse Response Graph of consumption expenditure and other structural shocks to oil price volatility

Response to Cholesky One S.D. Innovations \pm 2 S.E.
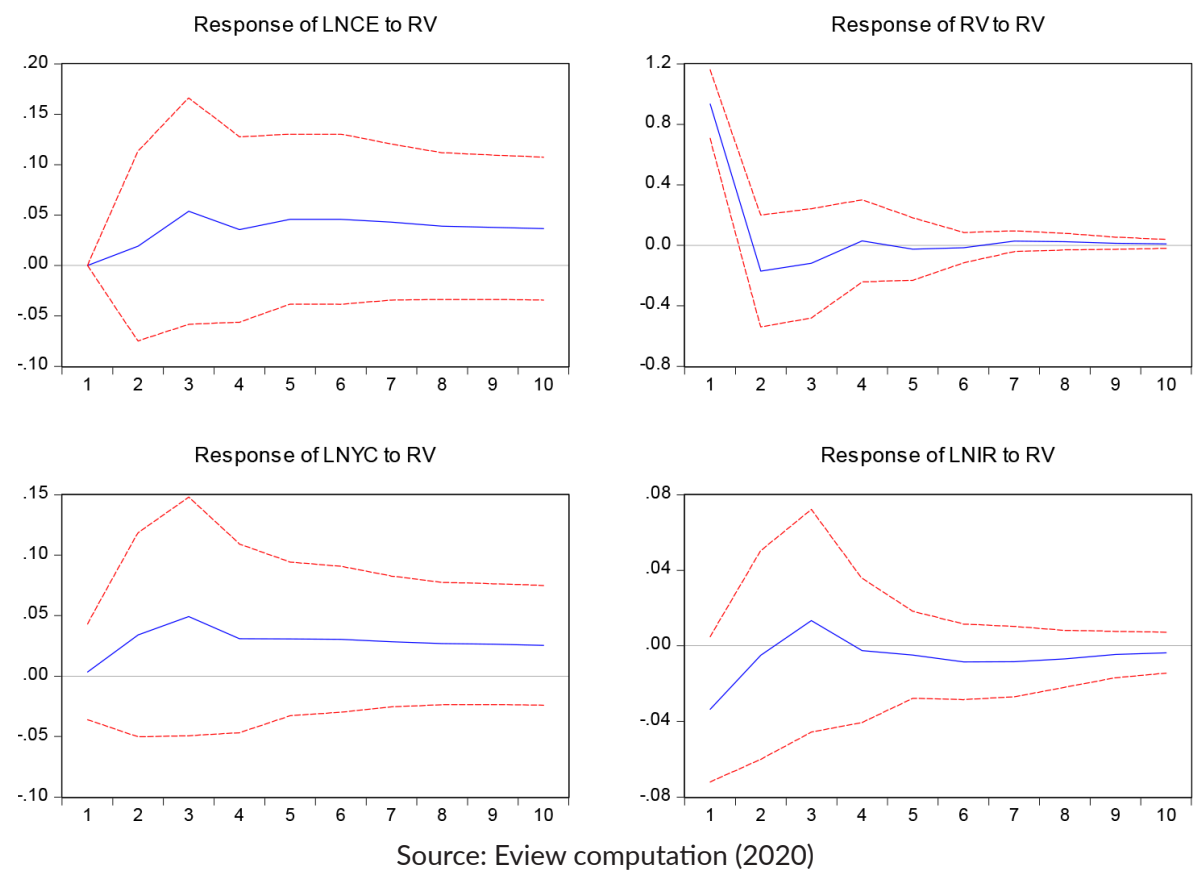

The findings of the IRF in Table 6 showed that all variables have a statistically significant response with a positive response to the oil price volatility. Consumer spending displayed a 
strong positive response in the 20-period dynamic one standard oil price variance innovation. Oil price volatility contributed to about 28.31 percent of the variation in consumption expenditure, suggesting that unexpected changes in oil prices during those horizons tend to influence consumption expenditure in Nigeria significantly.

Table 6. Impulse Response Analysis of Consumption expenditure

\begin{tabular}{|c|c|c|c|c|}
\hline Period & LNCE & RV & LNYC & LNIR \\
\hline 1 & 0.252461 & 0 & 0 & 0 \\
\hline 2 & 0.219253 & 0.019233 & 0.040748 & -0.020663 \\
\hline 3 & 0.188951 & 0.05379 & 0.036448 & 0.0394 \\
\hline 4 & 0.169243 & 0.035605 & 0.083914 & 0.05568 \\
\hline 5 & 0.169832 & 0.045876 & 0.071484 & 0.059194 \\
\hline 6 & 0.162877 & 0.045814 & 0.066109 & 0.053754 \\
\hline 7 & 0.160857 & 0.042956 & 0.05314 & 0.051859 \\
\hline 8 & 0.156703 & 0.03898 & 0.046529 & 0.04994 \\
\hline 9 & 0.152111 & 0.037786 & 0.041786 & 0.051041 \\
\hline 10 & 0.147151 & 0.036497 & 0.041227 & 0.052403 \\
\hline 11 & 0.143186 & 0.035958 & 0.040692 & 0.053291 \\
\hline 12 & 0.139704 & 0.035441 & 0.04009 & 0.05317 \\
\hline 13 & 0.136719 & 0.034856 & 0.038862 & 0.052533 \\
\hline 14 & 0.133931 & 0.034092 & 0.03753 & 0.051628 \\
\hline 15 & 0.131242 & 0.033333 & 0.036238 & 0.050746 \\
\hline 16 & 0.128584 & 0.0326 & 0.035203 & 0.049935 \\
\hline 17 & 0.125992 & 0.03193 & 0.034361 & 0.049174 \\
\hline 18 & 0.123478 & 0.031306 & 0.033641 & 0.048403 \\
\hline 19 & 0.121054 & 0.030712 & 0.03296 & 0.047601 \\
\hline \multirow[t]{5}{*}{20} & 0.118708 & 0.030129 & 0.032291 & 0.046768 \\
\hline & 2.829576 & 0.686894 & 0.843253 & 0.895857 \\
\hline & $53.84 \%$ & $13.07 \%$ & $16.04 \%$ & $17.05 \%$ \\
\hline & consumption shocks & $\begin{array}{l}\text { oil price volatility } \\
\text { shocks }\end{array}$ & income shocks & interest shocks \\
\hline & & $28.31 \%$ & $34.76 \%$ & $36.93 \%$ \\
\hline
\end{tabular}

Source: Author's computation (2020)

The paper also explored the forecast error variance decomposition (FEVD) with the Cholesky ordering of one-standard deviation innovation different shocks. The variance decomposition provides information about the relative significance of each random innovation in affecting the VAR system variables. Table 7 presented the variance decomposition of consumption expenditure and policy shocks in Nigeria. It also defined the percentage of the forecast error variance of the consumption expenditure explained by innovations to their shocks, oil price volatility, national income per capita, and interest rate shocks in the unrestricted VAR model system. The source of this forecast error demonstrated how every endogenous variable in VAR affects the present value and future value of the 
innovations. It is worth noting that volatilities in oil prices exert a positive influence on household consumption expenditures.

Table 7. Variance Decomposition of LNCE

\begin{tabular}{ccccc}
\hline Period & LNCE & RV & LNYC & LNIR \\
\hline 5 & 87.10063 & 2.819395 & 6.432930 & 3.647042 \\
10 & 83.44779 & 3.794820 & 7.136901 & 5.620493 \\
15 & 82.05121 & 4.076278 & 6.913377 & 6.959131 \\
20 & 81.30106 & 4.221865 & 6.726420 & 7.750653 \\
\hline
\end{tabular}

Source: Author's computation (2020)

Table 7 showed that shocks to oil price volatility, national income per capita, and interest rate accounted for less than $12.9 \%, 16.6 \%, 17.95 \%$, and $18.7 \%$ fluctuation in consumption expenditure (LNCE) across the fifth, tenth, fifteenth and twentieth period respectively. Surprisingly, the contribution of shocks to oil price volatility, national income per capita, and interest rate increased over time. Oil price volatility accounted for less than 2.8\%, 3.79\%, 4.07, and $4.22 \%$ for the fifth, tenth, fifteenth, and twentieth periods, respectively. Given the above impulse response analysis results, one can infer that that oil price volatility affects consumption expenditure but does not seem to contribute much in forecasting the consumption expenditure.

Figure 2. Inverse roots of AR characteristic polynomial

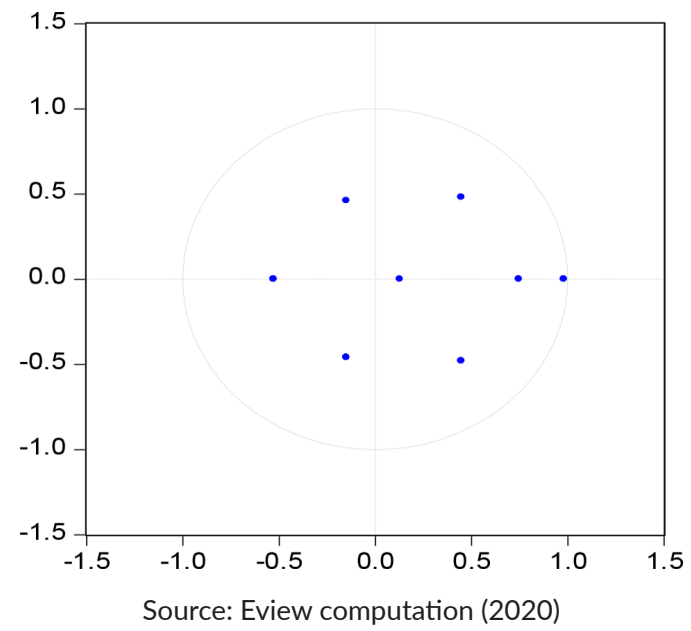

The results in Table 7 indicate that the resulting causal effects of oil prices' volatilities on unexpected shocks to specified variables in the model would prompt consumers to either postpone or continue purchases, given the uncertainty of future oil prices. However, the findings suggest that any persistence interference to oil supplies lessens them and consequently intensifies energy-related commodity prices if demand remains the same. Hence, consumers may then suspend purchases of or investments in energy-intensive goods and services. However, national per capita income appears to have the most significant response in the forecast error 
and therefore asks whether the impact on consumption is mainly due to oil prices or national per capita income. This result is in tandem with Blanchard \& Gali (2007), Edelstein \& Kilian (2009), Iwayemi \& Fowowe (2011), Blanchard \& Riggi (2013), Ramey (2016) that opined that the oil price shocks help in clarifying consumption growth, though little contribution.

A persistent increase in oil prices may further intensify overall price levels and compel inflation, which forces consumers to increase spending further. The result further explains that Nigeria has a low tolerance for oil price volatilities, which designates that consumer behavior in Nigeria is subject to the influences of oil price volatility. Nigeria is solely dependent on oil earning; a persistence period of significant price increases; therefore, it raises consumer price index levels, with adverse effects on production cost and household consumption spending. The paper further verified the VAR result's stability through the test for roots of the characteristic polynomial, as reported in Figure 2. The result shows a modulus that was less than one and which no root laid outside the unit circle. This result indicated that the estimated VAR was stable.

Besides, the VAR lag exclusion Wald test explores to confirm the joint significance of the variables. The result of the VAR lag exclusion tests presented in table 8 indicated that all endogenous variables in the model were jointly significant at each lag length order.

Table 8. VAR Lag Exclusion Wald Tests

\begin{tabular}{cccccc}
\hline Lag Length & LNCE & RV & LNYC & LNIR & Joint \\
\hline \multirow{2}{*}{ Lag 1 } & 21.57904 & 3.079202 & 23.83600 & 22.52143 & 66.09990 \\
& {$[0.000243]$} & {$[0.544660]$} & {$[8.62 \mathrm{e}-05]$} & {$[0.000158]$} & {$[0.0000]$} \\
\multirow{2}{*}{ Lag 2 } & 4.359385 & 7.190096 & 1.993690 & 7.616454 & 34.57504 \\
& {$[0.359548]$} & {$[0.126177]$} & {$[0.736920]$} & {$[0.106682]$} & {$[0.004542]$} \\
\hline
\end{tabular}

Source: Author (2020)

\section{Conclusion}

Oil remains a significant factor input and driver of economic growth. The resulting consequences vary from one nation to another due to their divergent economic structures and economies of scale. Consequently, the significant impacts on various macroeconomic factors have vigorously question in lengthy empirical studies. Given the prevailing gap, the paper applied the vector autoregressive model (VAR) to examine the impact of oil price volatility on Nigeria's household consumption expenditures from the sample period 1981-2019. The models where income, wealth, and interest rate incorporate as control variables suggested that oil price volatility has a statistically significant impact on household consumption. The findings show that expenditure on consumer spending responds positively and significantly to the standard error of changes in oil prices in structural terms over study periods.

Moreover, the decomposition of the variance did not affect the sign and significance of the household relationship between oil price volatility and consumption expenditure. The result shows that, for the fifth, tenth, fifteenth, and twentieth periods, oil price volatility is below 2.8 percent, 3.79 percent, 4.07 percent, and 4.22 percent, respectively. These outcomes are in pact with recent studies on the debate. Besides, the consumer income and interest rate 
shock accounted for about $34.76 \%$ and $36.93 \%$, respectively, of the total variation in the household consumption expenditure in Nigeria.

These results suggest that net consumer income and interest rates contribute to the household consumption expenditure in Nigeria. More income from oil exports, more funds for the government to support the firms and households in subsidies and interest-free loans. Accordingly, the paper offers that the Nigerian government employs the monetary and fiscal policies policy framework to strengthen the local production of household goods and non-oil goods export drive. Likewise, Nigeria's economies should develop alternative energy sources along with improving energy conservation across the industry.

\section{References}

Alsalman, Z., \& Karaki, M. (2019). Oil Prices and Personal Consumption Expenditures: Does the Source of the Shock Matter? Oxford Bulletin of Economics and Statistics, 81(2), 250-270. https://doi.org/10.1111/obes.12276.

Andersen, T. G., \& Bollerslev, T. (1998). Answering the Skeptics: Yes, Standard Volatility Models do Provide Accurate Forecasts. International Economic Review, 39(4), 885905. https://doi.org/10.2307/2527343.

Ando, A., \& Modigliani, T. (1963). The 'Life-Cycle' Hypothesis of Saving: Aggregate Implications and Test. American Economic Review, 53(1), 55-84.

Baumeister, C., \& Kilian, L. (2017). Lower Oil Prices and the U.S. Economy: Is This Time Different?. Brooking Papers on Economic Activity, 16, 287-357.

Baumeister, C., Kilian, L., \& Zhou, X. (2017). Is the Discretionary Income Effect of Oil Price Shocks a Hoax?. The Energy Journal, 39(SI2), 117-137.

Blanchard, O. J., \& Galí, J. (2008). The Macroeconomic Effects of Oil Price Shocks: Why are the 2000s so different from the 1970s? NBER Working Paper No. 13368.

Blanchard, O.J., \& Riggi, M. (2013). Why are the 2000s so Different from the 1970s? A Structural Interpretation of Changes in the Macroeconomic Effect of Oil Prices. Journal of the European Economic Association, 11(5), 1032-1052. https://doi.org/10.1111/ jeea.12029.

Chen, S. S., \& Hsu, K.W. (2012). Reverse Globalization. Does High Oil Price Volatility Discourage International Trade?. Energy Economics, 34(5), 1634-1643. https://doi. org/10.1016/j.eneco.2012.01.005.

Cologni, A., \& Manera, M. (2009). The Asymmetric Effects of Oil Shocks on Output Growth: a Markov-switching analysis for the G-7 countries. Economic Modelling, 26(1), 1-29. https://doi.org/10.1016/j.econmod.2008.05.006.

Edelstein, P., \& Kilian, L. (2009). How Sensitive are Consumer Expenditures to Retail Energy Prices?. Journal of Monetary Economics, 56(6), 766-779. https://doi.org/10.1016/j. jmoneco.2009.06.001.

Ferderer, J. P. (1996). Oil Price Volatility and the Macroeconomy: a Solution to the Asymmetry Puzzle. Journal of Macroeconomics, 18, 1-16.

Friedman, M. (1957). The Permanent Income Hypothesis. New Jersey: Princeton University Press. 
Hamilton, J. D. (1983). Oil and the Macroeconomy Since World War II. Journal of Political Economy, 91(2), 228-48.

Hamilton, J. D. (2005). Oil and the Macroeconomy. In Durlauf, S. and Blume, L. (eds.), The New Palgrave Dictionary of Economics, $2^{\text {nd }}$ ed. London: Palgrave MacMillan Ltd.

Hamilton, J. D. (2011). Nonlinearities and the Macroeconomic Effects of Oil Prices. Macroeconomic Dynamics, 15(S3), 364-378.

Iwayemi, A., \& Fowowe, B. (2011). Oil and the Macroeconomy: Empirical Evidence from Oil-Exporting African Countries. OPEC Energy Review, 35(3), 227-269. https://doi. org/10.1111/j.1753-0237.2011.00195.x.

Kilian, L. (2010). A Comparison of the Effects of Exogenous Oil Supply Shocks on Output and Inflation in the G7 Countries. Journal of European Economic Association, 6(1), 78-121. https://doi.org/10.1162/JEEA.2008.6.1.78.

Kilian, L., \& Vigfusson, R. (2014). The Role of Oil Price Shocks in Causing U.S. Recessions. CFS Working Paper Series 460. Frankfurt : Centre for Financial Studies.

Lescaroux, F., \& Mignon, V. (2008). On the Influence of Oil Prices on Economic Activity and Other Macroeconomic and Financial Variables. OPEC Energy Review, 32(4), 343380. https://doi.org/10.1111/j.1753-0237-2009-00157.x.

Mehra, Y., \& Petersen, J. (2005). Oil Prices and Consumer Spending. Federal Reserve Bank of Richmond Economic Quarterly, 91(3), 53-72.

Narayan, P. K., \& Narayan, S. (2007). Modelling Oil price Volatility. Energy Policy, 35(12), 6549-6553. https://doi.org/10.1016/j.enpol.2007.07.020.

Narayan, P., \& Gupta, R. (2015). Has Oil Price Predicted Stock Returns for Over a Century?. Energy Economics, 48, 18-23. https://doi.org/10.1016/j.eneco.2014.11.018.

Odusami, B. O. (2010). To Consume or Not: How Oil Prices Affect the Co-movement of Consumption and Aggregate Wealth. Energy Economics, 32(4), 857-867. https://doi. org/10.1016/j.eneco.2009.11.010.

Ogede, J. S., George, E. O., \& Adekunle, I. A. (2020). Exploring the Inflationary Effect of Oil Price Volatility in Africa's Oil Exporting Countries. Forthcoming in Facta Universitatis, Series: Economics and Organization.

Ramey, V.A. (2016). Lower Oil Prices and the U.S. Economy: Is This Time Different?: Comments and Discussion. Brookings Papers on Economic Activity Fall, 287-336.

Salisu, A. \& Fasanya, I. (2013). Modelling Oil Price Volatility with Structural Breaks. Energy Policy, 52, 554-562. https://doi.org/10.1016/j.enpol.2012.10.003.

Wang, Y., \& Wu, C. (2012). Forecasting Energy Market Volatility Using GARCH Models: can Multivariate Models Beat Univariate Models?. Energy Economics, 34(6), 21672181. https://doi.org/10.1016/j.eneco.2012.03.010.

Zaman, N. (2015). Do Oil Price Shocks Affect Household Consumption? Evidence from 5 OECD Countries. (Unpublished Thesis). Lund University.

Zhang, D., \& Broadstock, D. (2014). Impact of International Oil Price Shocks on Consumption Expenditures in ASEAN and East Asia. ERIA Discussion Paper 2014-24. 